\title{
Maps
}

I. The two Spains - a socio-economic view $\mathrm{XXX}$

2. Roman Hispania under Augustus 7-2 B.c.

3. Spain at the beginning of the tenth century

4. Modern Spain

142

\section{Genealogical Tables}

I. House of Burgundy 48

2. House of Barcelona 52

3. House of Trastámara $7 \mathrm{r}$

4. House of Austria (the Spanish Hapsburgs) $\quad 89$

5. House of Bourbon 112 